DOI: http://dx.doi.org/10.37253/jad.v2i2.6201

\title{
Kajian Konsep Arsitektur Bioklimatik Pada Masjid Al Warqa'a, Dubai, Uni Emirat Arab
}

\author{
${ }^{1}$ Ahmad Faisal, ${ }^{2}$ Finta Lissimia \\ 1,2 Jurusan Arsitektur, Fakultas Teknik, Universitas Muhammadiyah Jakarta, Jakarta \\ 2017460004@ftumj.ac.id finta.lissimia@ftumj.ac.id $^{2}$
}

Informasi Naskah

Diterima: 04/11/2021; Disetujui terbit: 06/12/2021; Diterbitkan: 31/12/2021;

http://journal.uib.ac.id/index.php/jad

\begin{abstract}
ABSTRAK
Masjid merupakan fasilitas umum penting bagi masyarakat beragama islam dengan fungsi sebagai tempat ibadah. Kenyamanan masjid dapat berpengaruh terhadap khusyu dalam proses beribadah. Pendekatan arsitektur bioklimatik adalah suatu solusi yang memaksimalkan manfaat dari kondisi eksisting melalui penerapan arsitektur bioklimatik pada bangunan masjid, dan untuk mengetahui bangunan masjid yang memiliki pengaruh langsung pada aspek-aspek dari arsitektur bioklimatik. Tujuan dari penelitian ini adalah mengetahui bagaimana penerapan arsitektur bioklimatik mempengaruhi bentuk dari masjid Al-Warqa'a. Metode penelitian ini menggunakan metode deskriptif kualitatif untuk mengetahui penerapan konsep arsitektur bioklimatik pada bangunan masjid sehingga dalam prinsip bioklimatik melalui layout dan bentuk bangunan, arah dan kondisi shading jendela, orientasi serta warna pada dinding, ventilasi bangunan, pemilihan material. dan site landscaping. Penelitian ini menggunakan metode pengumpulan data sekunder dengan variabel berupa suhu dalam ruangan, aliran udara, dan sinar matahari. Data sekunder adalah metode untuk survei data dengan mengumpulkan data melalui dari buku, jurnal, arsip, dan literatur dari penelitian sebelumnya yang berkaitan dengan prinsip arsitektur bioklimatik. Hasil yang didapatkan adalah dari 9 prinsip bioklimatik, ada 2 prinsip yang tidak diterapkan pada bangunan masjid Al-Warqa'a yaitu teras dan balkon. Namun untuk prinsip lainnya dapat diaplikasikan dengan menggunakan penyesuaian terhadap tiap prinsip tersebut.
\end{abstract}

Kata Kunci: arsitektur, bioklimatik, masjid, iklim, lingkungan, tropis kering

\section{ABSTRACT}

The mosque is an important public facility for the Muslim community with a function as a place of worship. The comfort of the mosque can affect humility in the process of worship. The bioclimatic architectural approach is a solution that maximizes the benefits of existing conditions through the application of bioclimatic architecture to mosque buildings, and to find out which mosque buildings have a direct influence on aspects of bioclimatic architecture. The purpose of this study is to find out how the application of bioclimatic architecture affects the shape of the Al-Warqa'a mosque. This research method uses descriptive qualitative methods to determine the application of bioclimatic architectural concepts to mosque buildings so that in bioclimatic principles through the layout and shape of the building, the direction and condition of window shading, orientation and color on the walls, building ventilation, material selection. and site landscaping. This study uses secondary data collection methods with variables such as indoor temperature, air flow, and sunlight. Secondary data is a method for surveying data by collecting data from books, journals, archives, and literature from previous research related to the principles of bioclimatic architecture. The results obtained are from 9 bioclimatic principles, there are 2 principles that are not applied to the Al-Warqa'a mosque building, namely terraces and balconies. However, other principles can be applied using adjustments to each of these principles. 


\section{Pendahuluan}

Kenyamanan visual maupun kenyamanan termal merupakan hal yang harus diperhatikan untuk membuat masjid, untuk meningkatkan kenyamanan jamaah yang melaksanakan ibadah di masjid tersebut. Sarana ibadah yang dapat memberikan kenyamanan visual dan kenyamanan termal bagi para pengguna masjid sebagai tempat beribadah, kajian ilmu, untuk baca tulis Al-Quran, dan lain sebagainya. Pada era informasi global saat ini contoh-contoh desain bangunan dapat diperoleh dengan mudah melalui buku, internet, dan sebagainya.

Yeang (1994) dalam Megawati \& Akromusyuhada mengatakan bahwa "Bioclimatology is the study of the relationship between climate and life, particulary the effect of climate on the health of activity of living things". Bioklimatik adalah ilmu yang mempelajari hubungan antara iklim dan kehidupan, khususnya pengaruh iklim terhadap kesehatan aktivitas makhluk hidup (manusia). Jadi bangunan bioklimatik adalah bangunan yang dibuat dengan desain yang berhubungan dengan iklim setempat dengan bertujuan sebagai penunjang kesehatan makhluk hidup yang beraktivitas didalamnya (manusia).

Persoalan muncul saat menciptakan masjid/rumah ibadah yang nyaman. Banyak terlihat sekarang adanya pembangunan masjid dimana-mana namun tanpa memperhatikan kenyamanan termal pada bangunan tersebut sehingga tujuan untuk memakmurkan masjid menjadi terhalang, karena kemungkinan masjid yang kurang nyaman membuat proses ibadah di dalamnya menjadi tidak terlalu khusyu.

Oleh karena itu, dari uraian fenomena di atas perlu dilakukan suatu kajian yang mengeksplorasi prinsip desain arsitektur bioklimatik khususnya pada bangunan masjid. Dari kajian ini diharapkan dapat membahas prinsip desain arsitektur bioklimatik pada bangunan masjid dan disimpulkan kebermanfaatan prinsip desain arsitektur bioklimatik pada bangunan masjid. Sehingga penerapan arsitektur bioklimatik pada bangunan masjid diharapkan dapat menjadi media pembelajaran mengenai bangunan yang tanggap terhadap iklim setempat.

\section{Kajian Pustaka}

Bangunan bioklimatik merupakan bangunan yang dibuat menggunakan desain melalui pendekatan hemat energi, dan berhubungan langsung dengan iklim setempat dan ilmu meteorologi, sehingga menjadi bangunan yang tidak dapat dipisahkan dari sifat lingkungannya dengan bentuk dan perencanaan serta tampilan bangunan yang menggunakan kualitas tinggi. (Yeang, 1996 dalam Tumimomor \& Poli, 2011).

Arsitektur bioklimatik menawarkan peluang menarik untuk jangkauan lingkungan, sosial, dan ekonomi. Banyak hal tentang energi, lingkungan dan proses daur hidup yang dapat dipelajari dan diterapkan. (Suwarno \& Ikaputra, 2020). Dari energi, lingkungan dan proses siklus kehidupan yang dimanfaatkan sebaik mungkin akan menghasilkan lingkungan, sosial dan perekonomian yang lebih unggul dan maju.

Dalam (Megawati \& Akromusyuhada, 2018) yang menjelaskan bahwa Arsitektur bioklimatik merupakan suatu pendekatan yang dapat memberikan wawasan, termasuk bagi seorang arsitek untuk memperoleh suatu penyelesaian desain dengan memperhatikan keterkaitan antara bentuk arsitektur dan lingkungan dalam iklim kawasan.

Arsitektur bioklimatik adalah seni membangun dengan metode hemat energi yang memperhatikan iklim setempat dan menyelesaikan masalah iklim dengan mengaplikasikannya pada elemen bangunan. (Rosang, 2016 dalam Cahyaningrum, dkk, 2017). Dalam Rahmadiah, dkk (2019) mengatakan bahwa bioklimatik adalah seni mendesain bangunan dengan metode hemat energi dengan memperhatikan iklim setempat dan memecahkan masalah iklim dengan mengaplikasikannya pada elemen bangunan.

Arsitektur bioklimatik merupakan suatu pendekatan desain yang mengarahkan arsitek untuk menyelesaikan desain dengan memperhatikan keterkaitan antara bentuk arsitektur dan 
lingkungannya, dalam hal ini iklim kawasan. Pendekatan ini nantinya dapat mengubah konsumsi energi bangunan (Dewangga, \& Setijanti, 2016).

Bioklimatis adalah ilmu yang mempelajari hubungan antara iklim dan kehidupan, khususnya pengaruh iklim terhadap kesehatan dan aktivitas sehari-hari (Arumsari, dkk, 2017). Dan dalam Yugaswara, dkk, 2014 mengatakan bahwa bioklimatik adalah salah satu bagian dari arsitektur hijau. Dengan pendekatan bioklimatik dapat mengarahkan arsitek untuk mendapatkan penyelesaian desain dengan memperhatikan hubungan antara bentuk arsitektur dan lingkungan sekitarnya.

Menurut Prianto et al. (2018) dalam Handoko (2019), semakin kuat desain arsitektur disebabkan karena pembagian yang penanganan dan pemanfaatan iklim yang terdapat dalam bangunannya. Hal ini menunjukkan pentingnya memperhatikan faktor iklim dengan bangunan untuk menghasilkan pembangunan yang tepat. Dengan memperhatikan faktor iklim tersebut, berpengaruh terhadap kenyamanan termal yang menjadi salah satu kenyamanan fisik pada bangunan dan manusia dapat melakukan berbagai cara dalam memodifikasi iklim luar menjadi kondisi yang nyaman.(Handoko, 2019)

Menurut Karyono (1996) dalam Handoko (2019), ada 2 (dua) aspek yang seharusnya dimiliki pada karya arsitektur yaitu kenyamanan psikis dan kenyamanan fisik. Kenyamanan psikis mencakup kepercayaan, agama, maupun hal-hal yang diukur secara kualitatif. kenyamanan fisik. mencakup kenyamanan ruang, kenyamanana penglihatan, maupun kenyamanan suhu.

(Yeang, 1994 dalam Handoko \& Ikaputra, 2019) mengatakan bahwa prinisp desain aristektur bioklimatik yaitu:

1. Core, Posisi struktur inti sangat penting dalam merancang bangunan bertingkat. Esensi servis tidak hanya bagian dari struktur, tetapi juga mempengaruhi kenyamanan internal dalam bangunan.

2. Orientasi, orientasi bangunan yang terbaik adalah menempatkan luas permukaan bangunan terkecil yang menghadap ke timur - barat dengan memberikan dinding luar di luar ruangan atau pada overhang terbuka.

3. Penempatan jendela, jendela harus menghadap utara atau selatan. Jika memperhatikan alasan estetis, penggunaan curtain walls dapat diterapkan pada fasad bangunan yang tidak langsung menghadap matahari. Shading dapat menjadi rencana untuk mengantisipasi radiasi matahari.

4. Penggunaan balkon, menempatkan balkon akan menjaga area bersih dari panel, sehingga mengurangi panas. Karena teras yang luas akan memudahkan untuk membuat taman. Karena tanaman dapat digunakan sebagai peneduh alami, dan sebagai area yang fleksibel, maka akan mudah untuk menambah fasilitas yang akan dibuat kedepannya.

5. Ruang transisi, dalam arsitektur bioklimatik didefinisikan sebagai zona antara bagian dalam dan luar bangunan. Area perwujudan dapat berupa atrium atau lokasi di tengah bangunan dan di sekitar bangunan dengan berfungsi sebagai ruang udara. kisi-kisi di atap gedung dapat mengarahkan angin dari atrium ke interior.

6. Desain pada dinding, dapat diartikan sebagai lapisan yang berfungsi sebagai pelindung kulit bangunan. Saat musim kemarau, desain dinding bisa menerapkan prinsip sekat yang harus selalu terbuka. Desain dinding berfungsi sebagai penyekat panas pada dinding, seperti massa bangunan yang bekerja untuk melepaskan panas pada siang hari.

7. Lansekap, pada bangunan tropis khususnya dalam hal ini tropis kering lantai dasar 
harus lebih terbuka dan menggunakan ventilasi alami karena hubungan lantai dasar dengan jalan juga penting.

8. Alat pelindung pasif, penggunaan passive shading pada dasarnya adalah pembiasan sinar matahari pada dinding yang berhadapan langsung dengan matahari sedangkan ventilasi harus digunakan (bahkan di ruangan ber-AC) meningkatkan udara segar dan hembusan udara panas keluar.

9. Penyekat panas pada lantai, insulator panas yang baik pada kulit bangunan dapat mengurangi pertukaran panas terik dengan udara dingin yang berasal dari dalam bangunan.

Dalam Yugaswara, dkk, 2014 mengatakan bahwa bioklimatik adalah salah satu bagian dari arsitektur hijau. Dengan 9 pendekatan bioklimatik tersebut dapat mengarahkan arsitek untuk mendapatkan penyelesaian desain dengan memperhatikan hubungan antara bentuk arsitektur dan lingkungan sekitarnya

\section{Metode Penelitian}

Metode yang digunakan pada proses kajian konsep arsitektur bioklimatik pada bangunan masjid adalah metode deskriptif kualitatif. Metode deskriptif kualitatif memiliki tujuan untuk mengetahui bagaimana penerapan konsep arsitektur bioklimatik pada bangunan masjid.

Data yang digunakan merupakan data sekunder yang berkaitan dengan konsep arsitektur bioklimatik pada bangunan masjid. Data sekunder yang digunakan berasal dari buku, jurnal, maupun literatur lain yang relevan

Metode analisis penelitian ini dilakukan seperti pada gambar 1, yaitu dengan cara mengaitkan prinsip arsitektur bioklimatik pada iklim tropis kering dengan bangunan studi kasus yang peneliti pilih yaitu: Masjid AI Warqa'a - Dubai. Jika telah dilakukan pembahasan terkait analisis dari studi kasus, maka akan menghasilkan kesimpulan dalam penelitian ini.

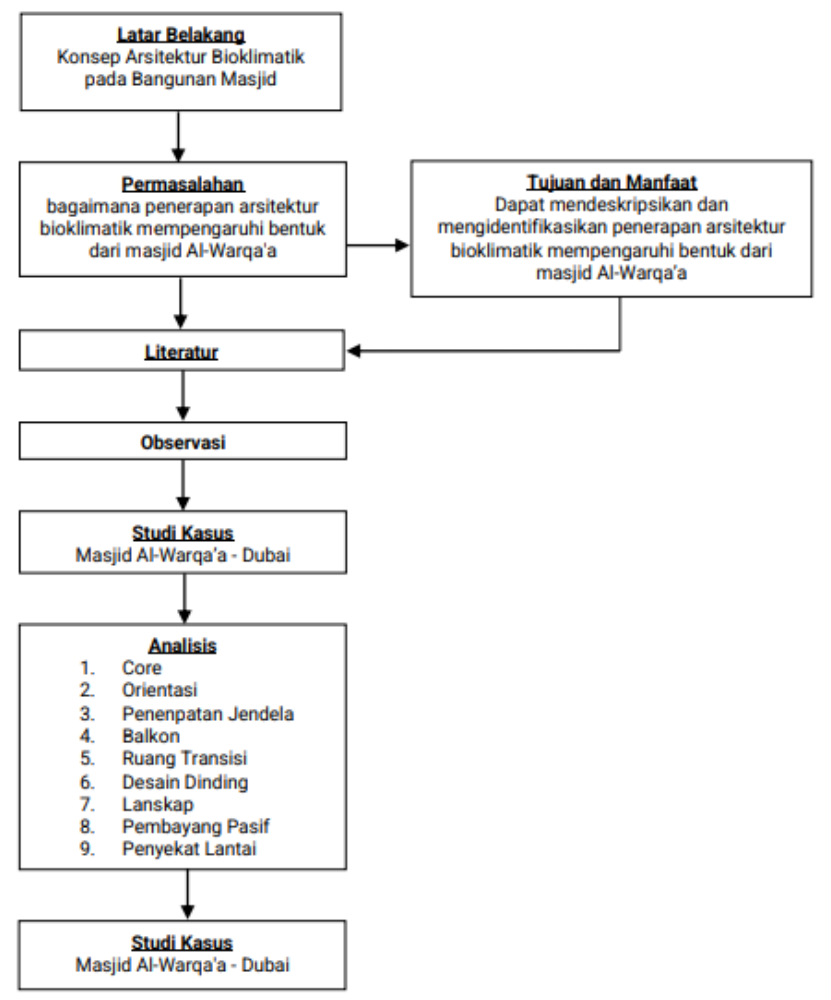

Gambar 1. Kerangka Analisis

Sumber: Dokumen Pribadi ,2021 


\section{Hasil dan Pembahasan}

Masjid Al-Warqa'a

Masjid AI-Warqaa merupakan masjid karya arsitek bernama Waiwai, dengan luas bangunan sebesar $1400 \mathrm{~m}^{2}$, dan di bangun pada tahun 2016. Dirancang dengan maksud sebagai ruang komunal untuk beribadah, Masjid Al Warqa'a adalah bangunan yang juga berfungsi sebagai tempat berkumpulnya masyarakat.

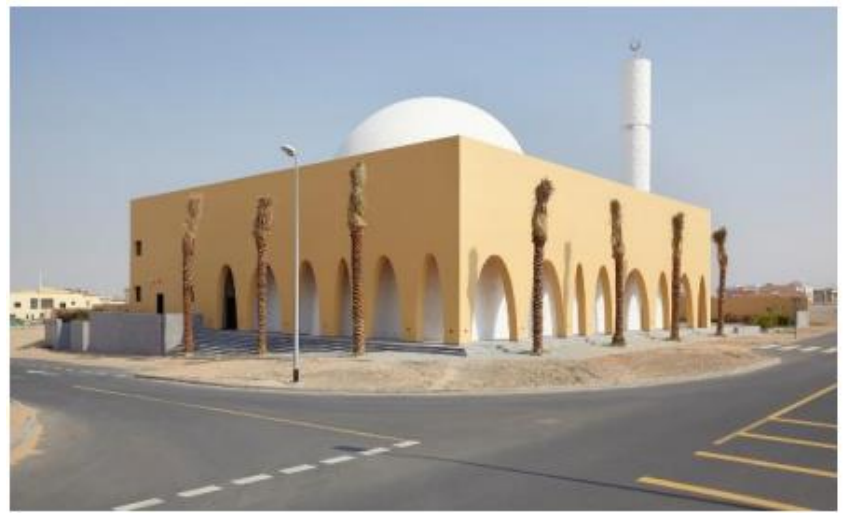

Gambar 2. Masjid Al-Warqa'a

Sumber: Archdaily ,2020

Masjid Al-Warqa'a berada pada suatu wilayah di Dubai, Uni Emirat Arab (UEA). Terletak di tenggara Dubai Creek, AI Warqa'a berbatasan di utara dengan Mirdif, di barat dengan Nad Al Hammar-Awir dan di selatan dengan Warsan atau Kota Internasional. Dulunya merupakan wilayah industri berpenduduk jarang yang dekat dengan batas kota Dubai, Al Warqa'a sekarang mengalami pertumbuhan yang cukup besar karena perkembangan International City dan proyek real estate lainnya di dekat daerah tersebut.

Banyaknya tipologi bangunan masjid yang menjamur di UEA berjenis Central Dome, para arsitek berusaha untuk kembali ke desain yang sederhana dan kurang menjadi ikon dengan tujuan sebagai ruang sosial. Masjid Al-Warqa'a kembali menggunakan kesederhanaan seperti rumah Nabi Muhammad pada abad ke-7 di Madinah, yang dianggap sebagai masjid pertama dalam sejarah.

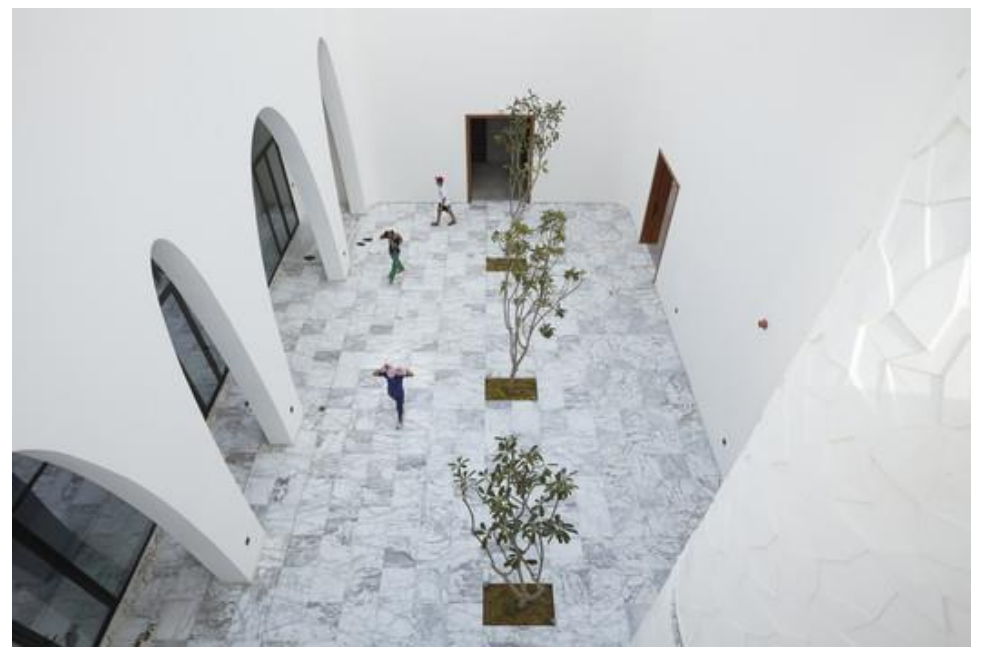

Gambar 3. Halaman Masjid Al-Warqa'a

Sumber: Archdaily ,2020

Secara konseptual dan spasial, arsitek merancang dengan memasukkan tema cahaya sebagai komponen fisik dan unsur spiritual dalam desain masjid. Penekanan pada cahaya 
alami tercipta melalui cahaya langit yang menyelimuti seluruh ruang, menghasilkan efek tersebar yang memberikan kesan interior yang halus. Cahaya juga memainkan peran lain. Ini berfungsi untuk menarik perhatian pada pergerakan matahari sebagai katalis dalam perubahan waktu, gerakan konstan menjadi pengatur visual dari siklus hariannya. Konsep gerak juga diintegrasikan ke dalam desain pola pada masjid. Berdasarkan relief bunga yang diabstraksi, pola bukaan di satu sisi jembatan apung menciptakan permainan cahaya dan bayangan yang selanjutnya menggaris bawahi gagasan tentang gerakan dan perubahan waktu shalat.

Materialitas dan desain pada Masjid AI Warqa'a memperhatikan struktur lokalitas dengan menggunakan Saudi Sandstone untuk fasad eksterior, masjid ini menjadi layaknya seperti pada lingkungan gurun tempat bangunan ini berada. Fasad luar berpasir kontras dengan interior putih masjid yang memberikan kesan masjid sebagai tempat perlindungan di sekitarnya, sebuah tempat peristirahatan dari unsur dunia yang keras

\section{Analisis}

\section{Penempatan Core}

Pada Masjid Al Warqa'a yang merupakan tipe bangunan rendah dengan berjumlah hanya dua lantai saja. Dengan fungsi sebagai tempat peribadatan masjid AI Warqa'a ini tidak mempunyai core sebagai mana struktur pada bangunan tinggi, sebagaimana dalam bangunan rendah masjid ini hanya menggunakan kolom dan balok saja. Dengan lantai pertama yang diperuntukan sebagai tempat sholat pria, wudhu dan ruang penunjang lainnya dan lantai dua diperuntukan untuk tempat sholat Wanita seperti pada gambar 4 .

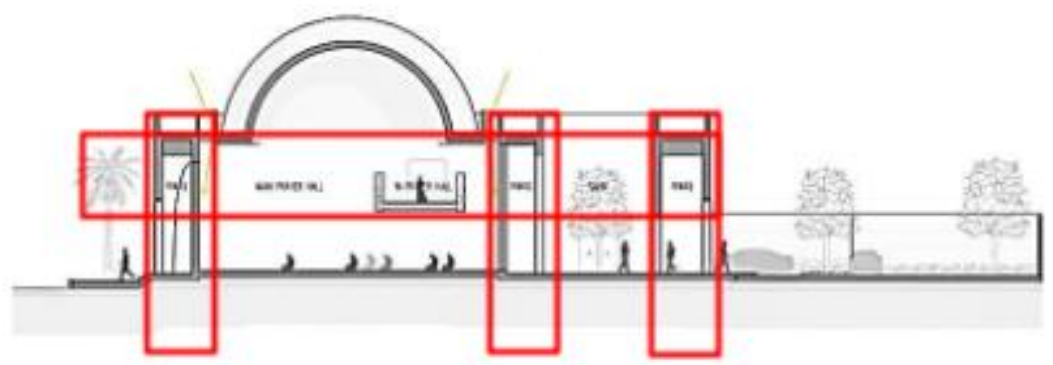

Gambar 4. Potongan Struktur Masjid Al Warqa'a

Sumber : Dokumentasi pribadi, 2020

\section{Orientasi Masjid}

Pada bangunan Masjid Al-Warqa'a juga dapat dilihat arah hadap atau orientasi dari bangunan ini ke arah kiblat di dubai yaitu barat sedikit menyerong ke arah barat daya beberapa derajat. Dengan bentukan bangunan yang persegi dapat membuat suhu di dalam bangunan menjadi merata dimanapun arah orientasi bangunan tersebut. Dapat dilihat pada gambar 5 yang komposisi pada bangunan tersebut terbentuk dengan bentukan persegi. Dalam bentukan masjid ini yang mengadaptasi dari Hypostyle Arab, yaitu bentuk awal masjid yang sering digunakan oleh Bani Umayyah yaitu suku di arab. Masjid Al Warqa'a Dubai memiliki bukaan yang berada pada tiap arah atau menyeluruh yang diperuntukan sebagai pencahayaan maupun udara yang masuk ke dalam bangunan. 


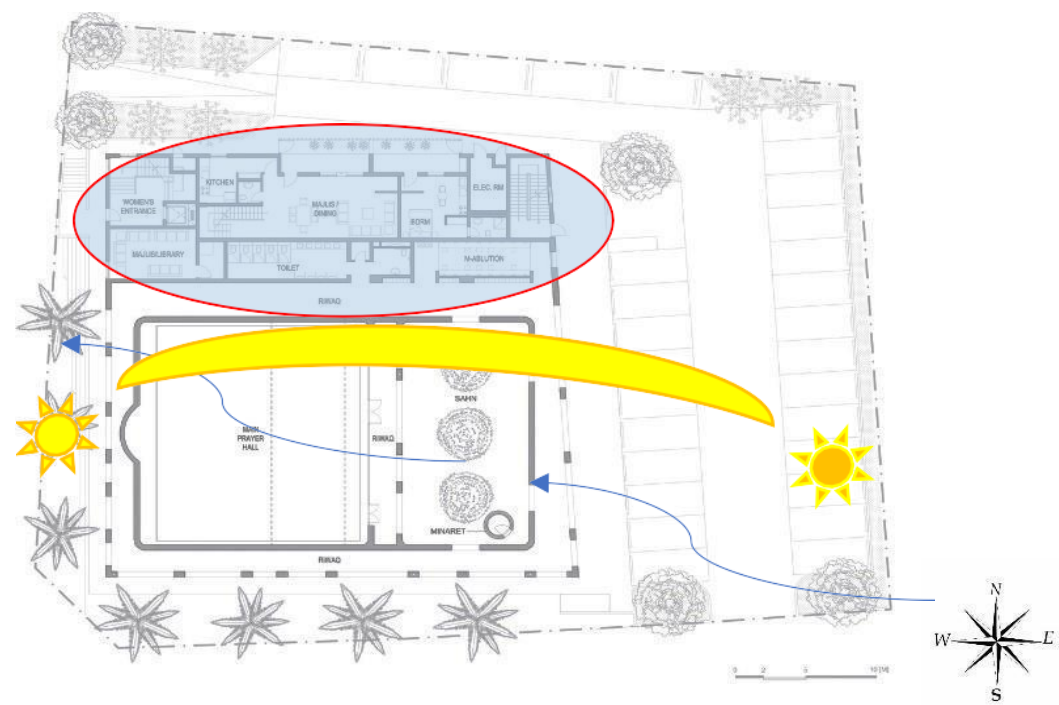

Gambar 5. Ground Floor Masjid Al Warqa'a - Dubai, United Arab Er, uı uи

Sumber: Sumber :Dokumen Pribadi, 2020

Pada bagian yang diarsir warna biru yang terdapat pada gambar 5 di atas menjelaskan bahwa ruang-ruang yang padat tersebut tidak adanya ventilasi silang untuk mengatur suhu ruang yang ada di dalamnya. Jadi pada masjid Al Warqa'a ini memiliki bagian yang masih kurang menerapkan konsep bioklimatik untuk ruang- ruang pendukung selain ruang ibadah. Ruang tersebut sangat banyak dan tidak adanya bukaan masuk dan bukaan keluar udara sehingga tidak adanya pergantian udara tersebut akan menyebabkan gangguan kesehatan bagi manusia yang beraktifitas di dalamnya karena udara didalam kurang sehat.

\section{Penempatan Bukaan Jendela}

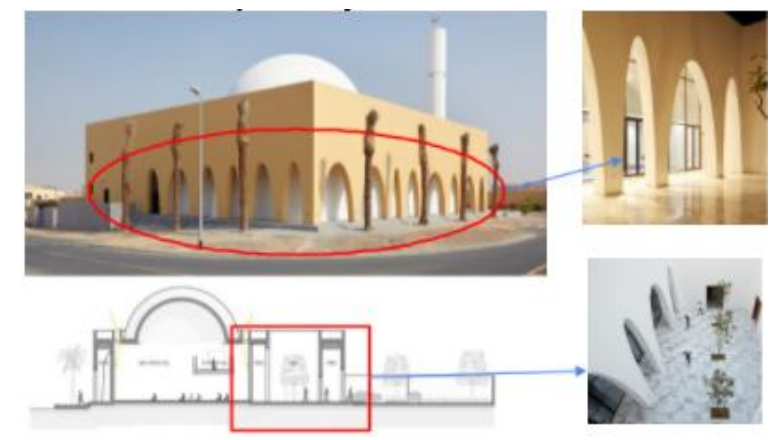

Gambar 6. Perspektif dan Potongan Masjid Al warqa'a

Sumber : Dokumen Pribadi, 2020

Dari gambar 6, dapat dilihat bahwa masjid AI Warqa'a tidak memiliki jendela sebagai fungsi ventilasi dan pencahayaan. Sebagai ganti dari fungsi ventilasi untuk pencahayaan, masjid ini menggunakan bukaan-bukaan yang lebar yang merupakan selubung dari masjid tersebut seperti pada gambar 6 , selain sebagai fungsi struktural selubung dengan bukaanbukaan yang besar berfungsi sebagai pembatas antara ruang luar dengan ruang dalam, selain itu juga sebagai pengatur udara dan pencahayaan yang masuk ke dalam masjid, serta pemecah udara yang masuk ke dalam bangunan dari halaman ke dalam ruang-ruang yang ada di sekitar dengan bantuan tanaman yang ada pada halaman tersebut. 


\section{Penggunaan Balkon}

Masjid dengan menggunakan selubung bangunan sebagai solusi dari pengaplikasian iklim daerah bangunan tersebut di bangun. Adanya selubung bangunan menjadikan penggunaan balkon dalam masjid ini tidak diaplikasikan, seperti pada gambar 7. Masjid ini memiliki 2 lantai, tetapi lebih memilih tidak menggunakan balkon yang dimana merupakan sebagai peneduh dari paparan sinar matahari, dengan adanya selubung yang menutupi bangunan merupakan cara yang paling efektif sebagai penanganan iklim gurun seperti tempat masjid Al Warqa'a ini di bangun. Hal ini disebabkan karena ciri khas bangunan gurun sangat berbeda dengan bangunan tropis dalam pengaplikasian dari beberapa komponen prinsip tersebut. Dengan demikian bahwa arsitektur bioklimatik cocok untuk semua iklim yang ada di bumi, namun dapat diaplikasikan dengan baik dalam iklim tropis dengan iklim 2 musim (panas dan dingin).

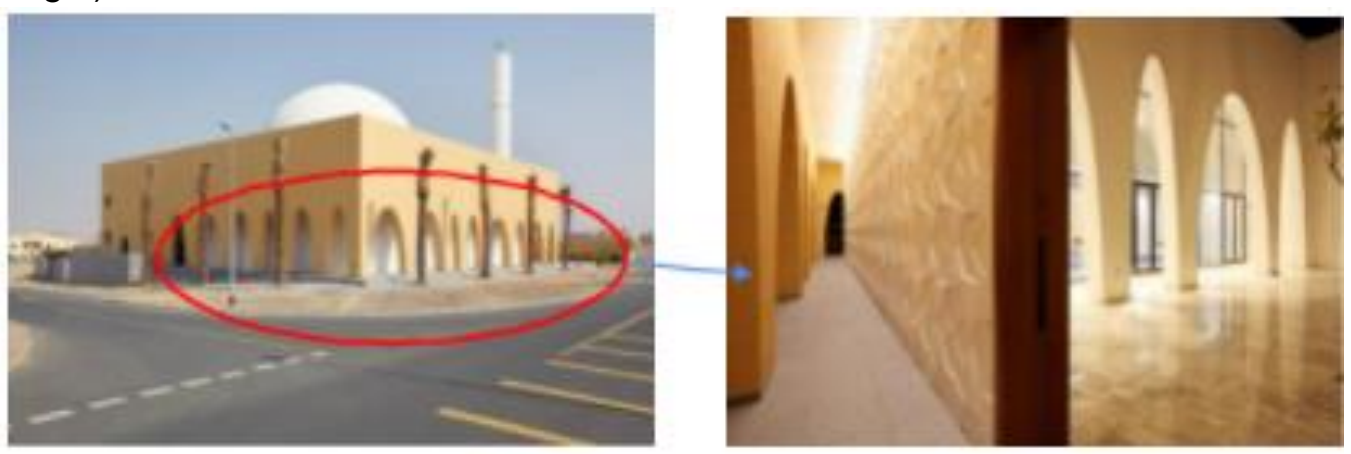

Gambar 7. Perspektif Masjid Al Warqa'a

Sumber : Dokumen Pribadi, 2020

\section{Ruang Transisi}

Pada masjid AI Warqa'a ruang transisi merupakan fungsi ruang sebagai tempat dimana perpindahan antara ruang luar dan ruang dalam, juga berfungsi sebagai pemecah udara yang masuk ke dalam ruangan dengan bantuan tanaman yang ada di halaman, serta juga sebagai pelindung dari adanya paparan sinar matahari langsung yang ada pada bangunan. Pada dasarnya ruang transisi dimanapun dan apapun bangunannya harus dibuat sebagai tempat dimana jika saja bangunan tersebut tanpa halaman depan, begitu pintu rumah dibuka langsung menuju jalan raya, akan dianggap kurang baik dan layak. Selain dengan fungsi kenyamanan termal maupun visual, ruang transisi juga berguna sebagai bentuk layak tidaknya sebuah bangunan tersebut, dimanapun tempat dan apapun iklim dari bangunan tersebut di bangunan

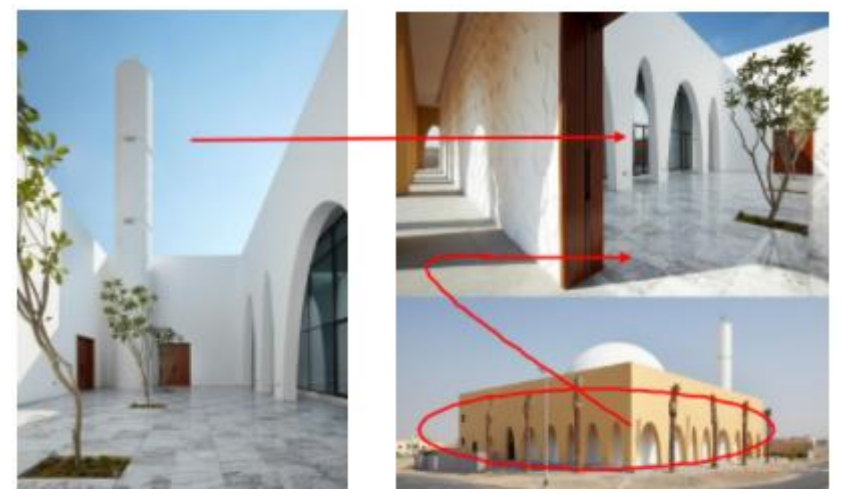

Gambar 8. Ruang Transisi Masjid Al Warqa'a Sumber : Dokumen Pribadi, 2020 


\section{Desain Dinding}

Pada masjid Al Warqa'a memiliki selubung bangunan yang merupakan bagian dari proses pemecahan permasalahan yang ada pada masjid, karena dengan kondisi iklim gurun yang panas dengan menggunakan pelindung tersebut diharapkan dapat menjadi isolator panas agar tidak masuk ke dalam bangunan. Selubung tersebut juga merupakan batasan antara ruang dengan fungsi sebagai pengatur cahaya matahari yang masuk, juga sebagai cross ventilation untuk mengatur udara pada masjid tersebut. Dan ketika saat adanya badai pasir selubung tersebut juga dapat melindungi bangunan dari paparan badai.
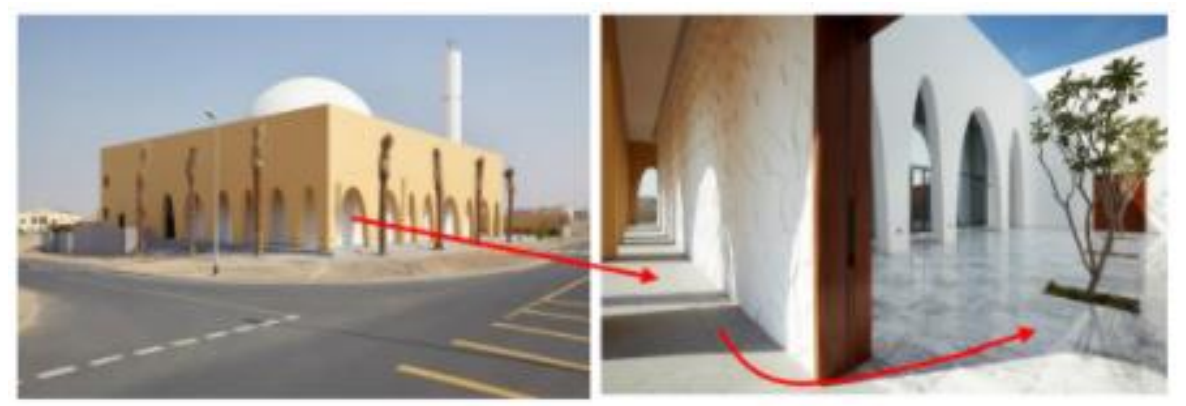

Gambar 9. Selubung Bangunan Masjid Al Warqa'a

Sumber : Dokumen Pribadi, 2020

\section{Lanskap}

Pada bangunan masjid Al-Warqa'a lanskap ataupun tanaman juga terdapat pada sekeliling bangunan masjid. Tanaman di bangunan ini digunakan selain sebagai pembatas site juga memiliki fungsi ekologi. Beberapa tanaman juga terlihat berada di bagian sahn (halaman) yang berfungsi sebagai pemecah dan penahan panas, aliran udara yang masuk ke dalam bangunan dapat menahan udara panas dan mengatur persebaran udara sehingga hanya udara sejuk saja yang masuk ke dalam bangunan. Karena iklim di Dubai merupakan iklim gurun yang ketika musim panas akan terasa sangat ekstrim panasnya dibanding dengan Indonesia.

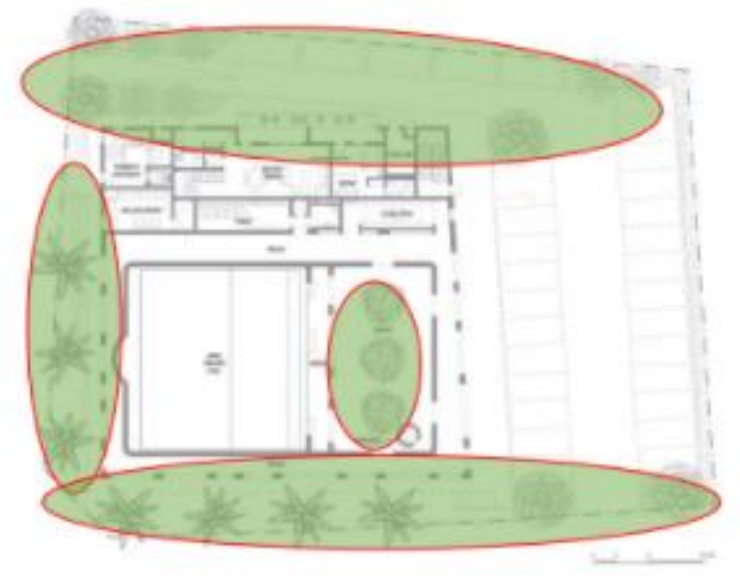

Gambar 10. Ground Floor Masjid Al Warqa'a - Dubai

Sumber : Dokumen Pribadi, 2020 


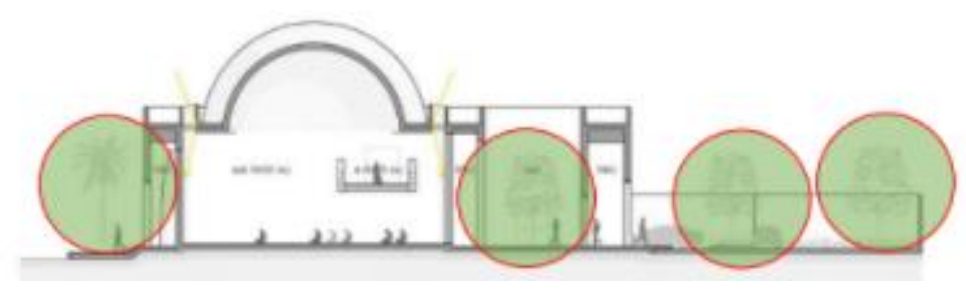

Gambar 11. Potongan Masjid Al Warqa'a - Dubai

Sumber : Dokumen Pribadi, 2020

\section{Desain Pasif}

Pada bangunan Masjid Al-Warqa'a karena demi menjaga efek dari iklim di sekitar yaitu iklim gurun, maka bangunan ini menggunakan selubung bangunan yang berbentuk persegi dengan menggunakan bukaan-bukaan besar sebagai pembatas antara ruang luar dan ruang dalam. Dan dengan menggunakan bukaan ventilasi yang saling bersebrangan (cross ventilation) sebagai pengatur suhu yang berada di dalam banguan tersebut. Juga terdapat celah udara di sisi kubah masjid yang sebagai pengatur udara yang masuk maupun udara yang keluar agar di dalam bangunan tersebut tetap nyaman, dapat dilihat dalam gambar 12 .

Pada Masjid Al Warqa'a mempunyai void sebagai pengatur cahaya yang ada pada bangunan tersebut sehingga mendapatkan bangunan dengan kenyamanan visual yang baik terutama pada ruang peribadatannya. Pada ruang penunjang tidak memiliki efek tersebut dikarenakan ruang tersebut terlalu tertutup.

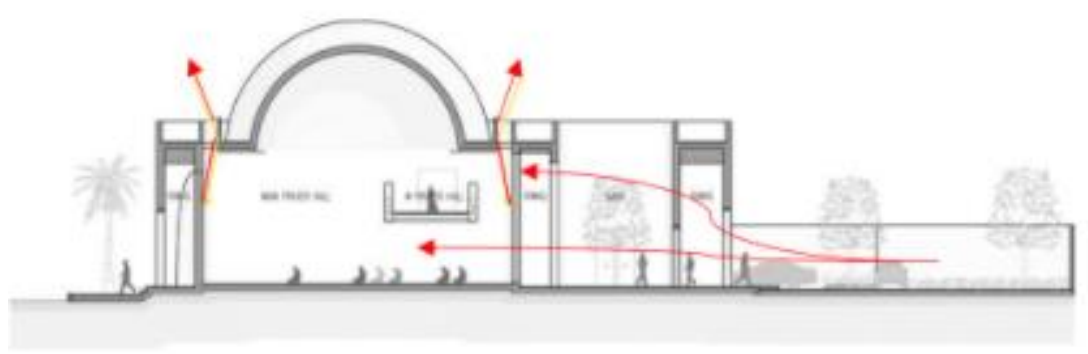

Gambar 12. Potongan Masjid Al Warqa'a - Dubai

Sumber : Dokumen Pribadi, 2020

9. Penyekat Panas pada Lantai

Selubung bangunan pada masjid Al Warqa'a merupakan isolator panas untuk mencegahnya paparan panas yang menyengat dari iklim gurun yang begitu panas, dan membuat bangunan tetap terjaga kesejukannya di dalam karena tidak adanya pertukaran dari panas dari luar bangunan ke dingin dari dalam bangunan itu sendiri

\section{Kesimpulan}

Arsitektur bioklimatik adalah suatu pendekatan desain dengan melibatkan iklim dari bangunan tersebut di banguan. Dari kesimpulan analis diatas dapat disimpulkan bahwa setiap tempat, lingkungan, dan iklim dari bangunan yang dibangun memiliki permasalahan yang dihadapi para desainer, pengaplikasian prinsip arsitektur bioklimatik dapat bermacam-macam jenis cara dan pembuatannya tergantung dari permasalahan yang dihadapi dari lingkungan dan iklim bangunan yang akan di bangun, dan tiap permasalahan memiliki solusinya masing- 
masing. Juga dapat disimpulkan bahwa arsitektur bioklimatik juga cocok untuk iklim tropis kering. Dari 9 prinisp bioklimatik, ada 2 prinsip yang tidak teraplikasikan dalam bangunan masjid tersebut, yaitu core dan balkon yang merupakan fungsi untuk bangunan tinggi (core) dan sebagai tempat tinggal (balkon). Berikut aspek yang terpengaruh langsung oleh arsitektur biolimatik dalam masjid Al-Warqa'a.

1. Orientasi, Tata letak massa bangunan didasarkan pada prinsip arsitektur bioklimatik dengan memperhatikan arah angin yang mempengaruhi panjang dan lebar bangunan serta letak bukaan pada bangunan tersebut. Arah hadap atau orientasi dari masjid AlWarqa'a ini ke arah kiblat di dubai yaitu barat sedikit menyerong ke arah barat daya beberapa derajat.

2. Penempatan Jendela, Masjid AI Warqa'a tidak memiliki jendela sebagai fungsi ventilasi dan pencahayaan, namun masjid ini menggunakan bukaan-bukaan yang lebar yang merupakan selubung dari masjid tersebut.

3. Ruang Transisi, Pada masjid Al Warqa'a ruang transisi merupakan fungsi ruang sebagai tempat dimana perpindahan antara ruang luar dan ruang dalam, juga berfungsi sebagai pemecah udara yang masuk ke dalam ruangan dengan bantuan tanaman yang ada di halaman, serta jug asebagai pelindung dari adanya paparan sinar matahari langsung yang ada pada bangunan.

4. Desain Dinding, memberan atau pelapis bangunan merupakan solusi dari permasalahan iklim pada masjid tersebut, masjid Al Warqa'a memiliki selubung bangunan yang merupakan bagian dari proses pemecahan permasalahan yang ada pada masjid, karena dengan kondisi iklim gurun yang panas dengan menggunakan pelindung tersebut di harapkan dapat menjadi isulator panas agar tidak masuk ke dalam bangunan..

5. Lanskap, pengelolaan ruang terbuka hijau di sekitar masjid dilakukan secara optimal guna mewujudkan penerapan prinsip arsitektur bioklimatik itu sendiri. Dari segi tanaman, maupun bentuk geografis serta iklim yang ada pada bangunan. Penanaman di tengah dan sekitar bangunan sangat berpengaruh pada pengurangan panas. Pada masjid AI-Warqa'a lanskap ataupun tanaman juga terdapat pada sekeliling bangunan masjid.

6. Desain Pasif, bentuk bangunan, secondary skin maupun penerapan konsep geografis dari lokasi bangunan merupakan penyelesaian yang baik bagi penanganan iklim dari lokasi bangunan. Peletakan serta besar kecilnya bukaan pada bangunan. Masjid AI-Warqa'a karena demi menjaga efek dari iklim di sekitar yaitu iklim gurun, maka bangunan ini menggunakan selubung bangunan yang berbentuk persegi dengan menggunakan bukaan-bukaan besar sebagai pembatas anatar ruang luar dan ruang dalam.

7. Penyekat Panas Pada Lantai, seperti halnya desain pada dinding, pembahasan penyekatan tersebut juga saling berhubungan dengan adanya lapisan-lapisan yang di aplikasikan dalam bangunan masjid.

\section{Daftar Pustaka}

Noviani Rahmadiah, Popi Puspitasari, Khotijah Lahji. 2019. Arsitektur Bioklimatik Dan Kearifan Lokal. IPTEKSEN, hal: 257-262.

Jarwa Prasetya Sih Handoko, Ikaputra 2019. Prinsip Desain Arsitektur Bioklimatik Pada Iklim Tropis. Jurnal Arsitektur, Vol. 6, No. 2.

Lia Amelia Megawati, Akhmad Akromusyuhada. 2018. Pendekatan Arsitektur Bioklimatik Pada Konsep Bangunan Sekolah Yang Hemat Energi. Prosiding Seminar Nasional Unimus (Volume 1).

Nurul Amalia, Agung Murti Nugroho, Damayanti Asikin. 2014. Fasad Bioklimatik Pada 
Rancangan Perpustakaan Umum Di Kedung Kandang Kota Malang. Jurnal Mahasiswa Jurusan Arsitektur, Vol.2, No.2.

Hajar Kusuma Cahyaningrum, Hardiyati, Rachmadi Nugroho. 2017. Implementasi Prinsip Desain Arsitektur Bioklimatik Pada Bangunan Perpustakaan Di Klaten. Jurnal IImiah Arsitektur Dan Lingkungan Binaan, Vol.15 No.2.

Faiz Dewangga B. D. dan Purwanita Setijanti. 2016. Pendekatan Arsitektur Bioklimatik Pada Bangunan Pesisir. JURNAL SAINS DAN SENI ITS Vol. 5, No.2.

Inggrid A.G Tumimomor dan Hanny Poli. 2011. Arsitektur Bioklimatik. MEDIA MATRASAIN, Vol.8, No.1.

Jarwa Prasetya Sih Handoko. 2019. Prinsip Desain Arsitektur Bioklimatik pada Iklim Tropis. Jurusan Arsitektur FTSP UII, Mahasiswa Program Doktor Arsitektur DTAP UGM, Vol.6 No.2.

Natalia Suwarno, Ikaputra. 2020. Arsitektur Bioklimatik Usaha Arsitek Membantu Keseimbangan Alam Dengan Unsur Buatan. Jurnal Arsitektur Komposisi, Vol.13, No.2.

Fatmadhita Arumsari, Yohannes Firzal, Mira Dharma Susilawati. 2017. Penerapan Arsitektur Bioklimatik Pada Science Technology Park Universitas Riau. Jom FTEKNIK Vol.4, No. 2.

Delfta Yugaswara, Beta Suryokusumo, Subhan Ramdlani 2014. Rumah Susun Dengan Konsep Bioklimatik Di Kota Malang. Jurnal Mahasiswa Jurusan Arsitektur, vol.2, No.1.

Syamsul Kurniawan, 2014. Masjid Dalam Lintas Sejarah Umat Islam. Khatulistiwa Journal Of Islamic Studies, Vol.4,No.2. 